\title{
GENDER DIVERSITY IN THE BOARDROOM: RAISING QUESTIONS ABOUT THE "COMPLY OR EXPLAIN" MODEL AND TARGETS IN CANADA
}

\author{
RIMA HALABI
}

\section{INTRODUCTION}

Canadian boards of directors and executive officer positions in publicly traded non-venture issuers lack diversity. In these roles, there is significant homogeneity in gender, racial background, age, sexual orientation, educational background, and career experience. ${ }^{1}$ The debate continues in the corporate governance world regarding whether homogeneous boardrooms run contrary to the best interests of the corporation and its shareholders. Stakeholders, including directors and investors, have come to recognize that diversity is essential on boards and in executive officer positions because of the various perspectives, skills, and experiences that will be brought into the boardroom. ${ }^{2}$

Gender parity remains a long-standing and prevalent problem, however. ${ }^{3}$ In Canada, 85 percent of all board seats in non-venture issuers are held by men, 34 percent have no women on the boards, and 34 percent have no women in executive officer positions. ${ }^{4}$ Some may argue that, in due time, women will reach parity with men without

Copyright @ 2019 by RIMA HALABI.

* Rima Halabi is a 2019 JD Candidate at Osgoode Hall Law School. She will be articling at a full service firm in Toronto. The author would like to thank Catherine McCall for her guidance in writing this article and the Western Journal of Legal Studies for their assistance in preparing it for publication. She would also like to express her gratitude to her family and friends for their endless support.

${ }^{1}$ Canadian Gender and Good Governance Alliance, "Directors' Playbook" (12 October 2018) at 2-3, online (pdf): Canadian Gender and Good Governance Alliance <www.cggga.ca/directors-playbook>. $230 \%$ Club Canadian Investor Group, "Statement of Intent" (September 2017), online (pdf): 30\% Club Canadian Investor Group <30percentclub.org/assets/uploads/Canada/PDFs/30_percent_Club _Canadian_Investor_Statement_FINAL_Sept_5_.pdf >; Russell Reynolds Associates, "Different Is Better-Why Diversity Matters in the Boardroom" (2009) at 5, online (pdf): Russell Reynolds Associates <www.russellreynolds.com/en/Insights/thought-leadership/Documents/different-is-better_0.pdf>.

${ }^{3}$ Canadian Coalition for Good Governance, "CCGG Gender Diversity Policy 2018" (2018) at 1, online (pdf): Canadian Coalition for Good Governance <www.ccgg.ca/wp-content/uploads/2019/03/CCGGGender-Diversity-Policy.pdf>.

${ }^{4}$ Canadian Securities Administrators, CSA Multilateral Staff Notice 58-310 Report on Fourth Staff Review of Disclosure Regarding Women on Boards and in Executive Officer Positions, CSA Notice 58310 (27 September 2018) at 2, 5, 8 . 
intervention. However, this point has been made since the 1970s and almost half a century later, the issue persists. ${ }^{5}$

In recent years, the discussion has shifted to considering what measures, if any, should be taken to address gender disparity. ${ }^{6}$ Some institutional investors are publicly expressing their support for gender diversity efforts. ${ }^{7}$ At the same time, boards are reluctant to take active measures to address gender disparity because they believe it is strictly an equality or fairness matter. ${ }^{8}$ A director's duty to act in the best interest of the corporation is seen as an obstacle to pursing equality-based initiatives that are not connected to effective and appropriate corporate governance. ${ }^{9}$ However, diversity in perspectives and diversity through the inclusion of marginalized groups who have historically been underrepresented are not disconnected ideas.

Gender diversity policy has received widespread support from corporate governance experts. The Canadian Gender and Good Governance Alliance (the "Alliance") holds that gender diversity is not just a matter of fairness but also of good governance. ${ }^{10}$ The Alliance maintains that gender parity on boards is a corporate governance problem, and they support increased representation of women on boards. ${ }^{11}$

Part I of this paper examines how the strategy for nominating directors and appointing executive officers has led to homogeneity in the attributes and perspectives of corporate decision-makers. Effective corporate governance requires diversity in perspectives, which includes gendered perspectives.

Part II explains the "business case" argument for addressing gender disparity. It will address the meta-analyses research that denies the validity of the business case argument and demonstrates why we should approach this research with caution: the meta-

\footnotetext{
${ }^{5}$ Carol Hansell, Letter from Carol Hansell to the Secretary of the Ontario Securities Commission (4 October 2013) Advisory Letter Re: OSC Staff Consultation Paper 58-401 Disclosure Requirement Regarding Women on Boards and in Senior Management at 1, online (pdf):

<www.hanselladvisory.com/content/uploads/20-Comment-Letter-Paper-58-401-OSC-Staff-ConsultationPaper.pdf>.

${ }^{6}$ Aaron A Dhir, Challenging Boardroom Homogeneity: Corporate Law, Governance, and Diversity (New York: Cambridge University Press, 2015) at 17.

${ }^{7}$ Andrew MacDougall et al, "2017 Diversity Disclosure Practices Report: Women in Leadership Roles at TSX-listed Companies" (18 September 2017) at 5, online (pdf): Osler, Hoskin \& Harcourt LLP <www.osler.com/en/resources/governance/2017/2017-diversity-disclosure-practices-report-women>.

${ }^{8}$ Dhir, supra note 6 at 65; Canadian Securities Administrators, CSA Roundtable Discussion-Third Review of Women on Boards and in Executive Officer Positions (transcript) Carol Hansell (Toronto: 14 October 2017) at 31.

${ }^{9}$ Dhir, supra note 6 at 65.

${ }^{10}$ Canadian Gender and Good Governance Alliance, supra note 1 at 5.

${ }^{11}$ Canadian Coalition for Good Governance, supra note 3.
} 
analyses take a narrow view of the business case, disregarding evidence that gender diversity benefits companies because women bring a different and unique perspective to the boardroom.

Part III outlines the measures taken by securities regulators in Canada to address gender disparity on boards of directors and in executive officer positions of non-venture issuers.

Part IV critically examines the results of the diversity disclosure of Canadian nonventure issuers since the implementation of the Canadian Securities Administrators' (the CSA) diversity disclosure rules.

In Part V, this paper will demonstrate that the CSA diversity disclosure rules are not a true "comply or explain" model. Part V will also recommend that securities regulators should require publicly traded companies to adopt a policy relating to the representation of women on their board. This policy should include a target percentage, chosen by a company, for the number of women on a company's board of directors and in its executive officer positions. In order to be effective, the new rules should be implemented under National Policy 58-201 Corporate Governance Guidelines. ${ }^{12}$

\section{PART I: HOMOGENEOUS BOARDS}

Canadian publicly traded non-venture issuers are facing a problem with diversity on boards of directors and in executive officer positions. The decision-makers are not representative of stakeholders, including their own investors and customers. ${ }^{13}$ Part of the reason that diversity has become an issue is because of the strategy used to select directors and managers. Boards look for candidates within their own social and professional networks to maintain collegiality among members. ${ }^{14}$ The unintended consequence of this approach is that individuals may be chosen despite the fact that they may not be effective on a particular board or fill a current gap in skill. ${ }^{15}$ Consequently, Canadian non-venture issuers have homogeneous boards made up of individuals with the same attributes, including gender, racial background, age, sexual orientation, educational background and career experiences. ${ }^{16}$

\footnotetext{
12 Ontario Securities Commission, OSC NP 58-201, (15 April 2005), online (pdf):

<www.osc.gov.on.ca/documents/en/Securities-Category5/rule_20050617_58-201_corp-govguidelines.pdf $>$.

${ }^{13}$ Lucy P Marcus, “Boardroom Diversity Means Better Business,” Huffington Post (4 May 2011), online: <www.huffingtonpost.com/lucy-p-marcus/boardroom-diversity-means_b_857303.html>.

${ }^{14}$ Canadian Gender and Good Governance Alliance, supra note 1 at 4; Dhir, supra note 6 at 101.

${ }^{15}$ Canadian Gender and Good Governance Alliance, supra note 1 at 5; Russell Reynolds Associates, supra note 2 at 1.

${ }^{16}$ Canadian Gender and Good Governance Alliance, supra note 1 at 14.
} 
There are three different sets of attributes that contribute to a person's unique perspectives. These sets are termed as experiential, demographic, and personal attributes. ${ }^{17}$ Experiential attributes include education and industry experience; demographic attributes include gender and racial background; and personal attributes include personality and interests. ${ }^{18}$ The danger of uniformity stems from the fact that an individual's attributes and, thus, his or her perspective shapes his or her skill set, approach to problem solving, opportunity identification, and risk assessment. ${ }^{19}$

Effective corporate governance requires board members to have a wide range of perspectives to encourage collaborative tension and better decision-making. ${ }^{20}$ Our perspectives are based on our experiential, demographic, and personal attributes. Consequently, the nomination and selection process for directors and executive officers must take into consideration demographic attributes, including gender, racial background, and so on. ${ }^{21}$ The inclusion of a wide range of perspectives is what is meant by the reference to diversity. ${ }^{22}$

Gender diversity is not merely about ensuring the inclusion of women. Gender may only be one attribute, yet it contributes to an individual's perspective. ${ }^{23}$ Furthermore, gender influences experiential attributes like educational and industry experience, which also leads to a gendered perspective. ${ }^{24}$ Strategies for nominating directors and appointing executive officers must be changed in order to reduce homogeneity in the attributes and perspectives of corporate decision-makers.

\section{PART II: THE BUSINESS CASE}

In response to the assertion that gender disparity is not an appropriate corporate governance issue, the "business case" argument is frequently advanced. ${ }^{25}$ The "business case" claims that issuers who have diversity on their boards and among their executive officers achieve better financial results. ${ }^{26}$ In fact, two studies demonstrate a positive

\footnotetext{
${ }^{17}$ Russell Reynolds Associates, supra note 2 at 8.

18 Ibid.

${ }^{19}$ Ibid at 9.

${ }^{20}$ Ibid.

21 Ibid.

${ }^{22}$ Marcus, supra note 13; Canadian Securities Administrators, supra note 8 at 11 (Maureen Jensen).

${ }^{23}$ Dhir, supra note 6 at 157.

${ }^{24}$ Ibid.

${ }^{25}$ Ibid at 63.

${ }^{26}$ Catalyst, "The Bottom Line: Connecting Corporate Performance and Gender Diversity" (2004) at 3, online (pdf): Catalyst <www.catalyst.org/wp-content/uploads/2019/01/The_Bottom_Line_Connecting_ Corporate_Performance_and_Gender_Diversity.pdf $>$.
} 
correlation between greater diversity among corporate decision-makers and more successful financial results.

One of the studies examining this correlation was conducted by Catalyst, a global non-profit organization that conducts research on women in the workplace. ${ }^{27}$ Catalyst studied the connection between gender diversity in top management and financial performance in Fortune 500 companies from 1996 to $2000 .^{28}$ The measures that were used to determine financial performance were "return on equity" and "total return to shareholders." The study found that companies with the highest representation of women financially outperformed companies with the lowest representation. ${ }^{29}$ The results of the study are strengthened by the finding that companies with the best financial performance had more women in top management. ${ }^{30}$

Another study that examined the business case was conducted by McKinsey \& Company, a global management consulting firm that has been researching the topic of diversity in the workplace. They studied gender diversity in leadership and its relationship to financial performance, measured through earnings before interest and tax. ${ }^{31}$ This study looked at companies in Canada, the United Kingdom, Latin America, and the United States. The results of the study exhibited that companies with the most diverse leadership were 15 percent more likely to have financial returns that exceed the national industry median. ${ }^{32}$ McKinsey \& Company concluded that there is a statistically significant relationship between diverse leadership and financial performance. ${ }^{33}$

\section{Criticism of Meta-Analyses Research}

Two recent meta-analyses deny the validity of the business case. ${ }^{34}$ The metaanalyses summarized prior peer-reviewed studies and argued that there is, at most, a weak relationship between financial performance and board gender diversity. ${ }^{35}$ The analyses

\footnotetext{
27 Ibid.

28 Ibid at 4.

${ }^{29}$ Ibid at 2.

${ }^{30}$ Ibid at 10 .

${ }^{31}$ Vivian Hunt, Dennis Layton \& Sara Prince, "Why Diversity Matters” (2015) at 1, online (pdf):

McKinsey \& Company <www.mckinsey.com/ /media/McKinsey/Business\%20Functions/Organization/ Our\%20Insights/Why\%20diversity\%20matters/Why\%20diversity\%20matters.ashx>.

${ }^{32}$ Ibid.

33 Ibid.

${ }^{34}$ Knowledge@Wharton, “Does Gender Diversity on Boards Really Boost Company Performance?” (18 May 2017), online: Knowledge@Wharton <knowledge.wharton.upenn.edu/article/will-gender-diversityboards-really-boost-company-performance>.

35 Ibid.
} 
concluded that "research results suggest that there is no business case ... [w] omen should be appointed to boards for reasons of gender equality, but not because gender diversity on boards leads to improvements in company performance." 36 This conclusion should be approached with caution for three important reasons, however.

Meta-analyses may have shown that the relationship between board gender diversity and improved financial performance is not definitive, but this does not necessitate a conclusion that there is no relationship between board gender diversity and improved financial performance. In fact, one study found a statistically significant relationship, while another found a neutral relationship. ${ }^{37}$ Moreover, the studies conducted by McKinsey \& Company and Catalyst both found that the companies with the most gender diversity were more likely to have better financial performance. Numerous other studies have made similar findings and, as result, boards are still encouraged to pursue gender diversity in order to enhance company performance. ${ }^{38}$

The studies concluding that gender diversity does not lead to improved financial performance do not account for the fact that the companies they studied did not have sufficient female representation. The findings of the meta-analysis are not surprising when we recognize that mere token representation of women is not enough to influence boards. Even those reporting on the results of the meta-analyses admit that "[w]hen individuals are minorities, tokens, or outliers in a group, they often self-censor, holding back from expressing beliefs and opinions that run counter to the beliefs and opinions of the majority of the group." 39 This statement is supported by critical mass theory that maintains that there must be gender balance, or significant representation, for women to actually influence board decision-making. ${ }^{40}$

In fact, research has found that a board must be composed of at least 30 percent women for female voices to be heard. ${ }^{41}$ The Canadian 30\% Club Investor Group (the " $30 \%$ Club") explains that " $30 \%$ is the level at which critical mass is achieved and contributions of a minority group cease being representative of that particular group and begin to be judged on their own merit." ${ }^{2}$ The $30 \%$ Club believes that it is possible for

\footnotetext{
36 Ibid.

${ }^{37}$ Hunt, Layton \& Prince, supra note 31 at 1.

${ }^{38}$ Canadian Gender and Good Governance Alliance, supra note 1 at 9.

${ }^{39}$ Knowledge@Wharton, supra note 34.

${ }^{40}$ Dhir, supra note 6 at 148

${ }^{41}$ Alexandra Posadski, “OSC Weighs Next Steps to Improve Board Diversity," The Globe and Mail (24

October 2017), online: <www.theglobeandmail.com/report-on-business/osc-mulls-next-steps-to-improveboard-diversity/article36705720>; Armina Ligaya, "Panel Urges OSC to Compel Companies to Set Targets for Women on Boards," Investment Executive (24 October 2017), online: <www.investment executive.com/news/from-the-regulators/panel-urges-osc-to-compel-companies-to-set-targets-forwomen-on-boards>.

$4230 \%$ Club Canadian Investor Group, supra note 2.
} 
Canada to achieve female representation of 30 percent on boards and in executive officer positions; however, this has not occurred yet. As a result, it is unlikely that research will be able to conclusively determine the relationship between board gender diversity and improved financial performance until gender disparity is addressed. Nevertheless, inconsistent research should not deter companies from implementing diversity policies and working toward best practices.

Moreover, meta-analyses should be approached with caution because they take a narrow view of the business case. The research claims that there is no business case because there is no conclusive relationship between gender diversity and improved financial performance. However, the business case goes beyond financial performance because gender diversity leads to numerous benefits for issuers as a result of the diverse and unique perspectives that women bring to the boardroom. ${ }^{43}$ Osgoode Hall Law School Professor Aaron Dhir terms this the "modified business case." 44

\section{Gendered Approach to Corporate Governance and Decision-Making}

Following the implementation of quotas for female representation on boards in Norway, Dhir conducted a qualitative study with Norwegian male and female corporate directors. ${ }^{45}$ He found that women approach corporate governance and decision-making differently than men. ${ }^{46}$ This supports the argument that gender contributes to diversity of perspectives in the boardroom. An important finding from the study was that diversity in professional or educational background is not a substitute for gender diversity. ${ }^{47}$ The study found that female directors possessed three broad characteristics that distinguish them from their male counterparts. ${ }^{48}$ These characteristics have the power to benefit companies.

First, women possess intellectual and experiential diversity that results in different "perspectives, experiences, angles, and viewpoints." 49 This cognitive difference leads to improved decision-making, long-term benefits for the business, and the ability to consider alternative solutions to complex issues. ${ }^{50}$ Dhir explains that "[w]ith respect to why female directors in particular bring intellectual and experiential diversity to the boardroom, most

\footnotetext{
${ }^{43}$ Catalyst, supra note 26 at 2-3; Dhir, supra note 6 at 280; Canadian Coalition for Good Governance, supra note 3.

${ }^{44}$ Dhir, supra note 6 at $148-49$.

${ }^{45}$ Ibid at 107.

${ }^{46}$ Ibid at 101.

${ }^{47}$ Ibid at 154-55.

${ }^{48}$ Ibid at 119.

${ }^{49}$ Ibid at 119-20.

${ }^{50}$ Russell Reynolds Associates, supra note 2 at 5.
} 
felt that there was something specifically related to gender at play." ${ }^{51}$ One example of the benefit of gendered perspectives is that while men are more risk-seeking, women tend to be more risk-averse, which leads to a good balance on the board for effective risk mitigation and crisis management. ${ }^{52}$

Second, women possess a different level of diligence than men. ${ }^{53}$ Women are more likely to probe deeply into the issues by asking "more questions, more challenging questions, more interesting and counterintuitive questions." "W4 Women do so because they prefer to fully understand the material issue and the finer details before coming to a decision. Part of the reason why women ask different questions is because they have different perspectives, experiences, and knowledge. Further, women were found to be more diligent because they were more prepared for meetings and asked for more information and documentation before making a decision. ${ }^{55}$

Third, women have a different "style of engagement" than men. ${ }^{56}$ Women have a different approach to decision-making that is more relational, collaborative, and dynamic. This approach is executed through open communication, asking for input, and engaging everyone at the table. As a result, gender diversity on boards could promote broader and higher quality discussion. ${ }^{57}$ The common theme among the three characteristics is the ability of gender diversity to improve decision-making. Gender diversity leads to the ability to make more innovative and creative decisions because it promotes a variety of problem-solving strategies. ${ }^{58}$

The danger with homogeneous boards, comprised of like-minded individuals, is the tendency for "groupthink" to form. ${ }^{59}$ Groupthink is defined as "a mode of thinking where pressure for unanimity overwhelms motivation to appraise the alternative course of action realistically." 60 When individuals think in the same way, they are more likely to agree to solutions that are not ideal. ${ }^{61}$ The tendency to go along with the group is pervasive because it occurs unconsciously. Diversity is an effective strategy for avoiding

\footnotetext{
${ }^{51}$ Dhir, supra note 6 at 119.

${ }^{52}$ Ibid at 124.

${ }^{53}$ Ibid at 120.

${ }^{54}$ Ibid.

${ }^{55}$ Dhir, supra note 6 at 121.

${ }^{56} \mathrm{Ibid}$ at 122.

${ }^{57}$ Ibid at 123 .

${ }^{58}$ Canadian Gender and Good Governance Alliance, supra note 1 at 6.

${ }^{59}$ Ibid.

${ }^{60}$ Ernst \& Young, "Audit Committee Bulletin: The Dangers of Groupthink" (January 2014) at 3, online (pdf): Ernst \& Young <www.ey.com/Publication/vwLUAssets/EY-Audit-Committee-Bulletin-Issue6/\$FILE/EY-Audit-Committee-Bulletin-Issue-6.pdf $>$.

${ }^{61} \mathrm{Ibid}$.
} 
groupthink because less homogeneous groups will have different ideas and ways of thinking about issues that may lead to more innovative and creative results. ${ }^{62}$

Improved decision-making and diverse perspectives make boards more effective at meeting their customers' needs. ${ }^{63}$ Gender diversity is especially important in this regard because women play a large role in purchasing decisions, and their economic power is growing. ${ }^{64}$ It is in a company's best interest to have women on boards because companies will better understand the products and services that customers need. Accordingly, boards will be better equipped to respond to changes and trends in the market. ${ }^{65}$

In addition to helping meet customer needs, gender diversity will make boards and executive officers more representative of shareholders and stakeholders, including suppliers, regulators, and lenders. ${ }^{66}$ Russell Reynolds Associates, a global executive search and assessment firm, interviewed directors from Fortune 500 companies about diversity in the boardroom. The directors expressed that it is in investors' interests to have a diverse board that can "anticipate and consider the concerns and perspectives of all key constituencies." $" 67$

Gender diversity on a board may also allow companies to achieve numerous advantages over their competitors. These benefits include the opportunity to access a broader pool of educated and skilled individuals, the ability to develop better products, greater employee satisfaction, more effective monitoring of CEOs, better customer service relations, and the ability make more innovative decisions. ${ }^{68}$ The McKinsey \& Company study concluded that the improved financial performance exhibited by companies with diverse boards and senior management is a result of these numerous benefits. ${ }^{69}$ Over time, these benefits could allow issuers to achieve better performance.

\footnotetext{
${ }^{62}$ Hunt, Layton \& Prince, supra note 31 at 13; Canadian Gender and Good Governance Alliance, supra note 1 at 6 .

${ }^{63}$ Canadian Gender and Good Governance Alliance, supra note 1 at 3

${ }^{64}$ Catalyst, supra note 26 at 3.

${ }^{65}$ Hunt, Layton \& Prince, supra note 31 at 11; Canadian Securities Administrators, supra note 8 at 24 (Ungad Chadda).

${ }^{66}$ Catalyst, "Gender Diversity on Boards in Canada: Recommendations for Accelerating Progress," report commissioned by the Government of Ontario (2016) at 7, online (pdf): <https://www.catalyst.org/wpcontent/uploads/2019/01/gender_diversity_on_boards_in_canada_final_pdf_version.pdf >.

${ }^{67}$ Russell Reynolds Associates, supra note 2 at 5.

${ }^{68}$ Catalyst, supra note 26 at 2-3; Canadian Coalition for Good Governance, supra note 3; Canadian Gender and Good Governance Alliance, supra note 1 at 2, 5; Russell Reynolds Associates, supra note 2 at 9; Hunt, Layton \& Prince, supra note 31 at 2.

${ }^{69}$ Hunt, Layton \& Prince, supra note 31 at 9; Canadian Coalition for Good Governance, supra note 3.
} 
There is significant debate over whether the differences between genders result from experiences or human nature. However, Dhir explains that "conclusions that link gender to particular dynamics of collective decision-making and governance do not all depend" on the nature versus nurture debate. ${ }^{70}$ Despite the continued debate regarding the benefits of gender diversity, securities regulators in Canada have attempted to increase the representation of women on boards and in executive officer positions.

\section{PART III: CANADIAN SECURITIES ADMINISTRATORS' GENDER DIVERSITY DISCLOSURE REQUIREMENT}

On December 31, 2014, securities regulators in various provinces and territories across Canada implemented amendments to Form 58-101F1 Corporate Governance Disclosure of National Instrument 58-101 Disclosure of Corporate Governance Practices (the Diversity Disclosure Rules). ${ }^{71}$ These amendments set out a disclosure requirement regarding the representation of women on boards and in executive officer positions. ${ }^{72}$ The Diversity Disclosure Rules require non-venture issuers to disclose the following:

- Director term limits and other mechanisms of board renewal;

- Policies regarding the representation of women on the board;

- Consideration of the representation of women in the director identification and selection process;

- Consideration given to the representation of women in executive officer appointments;

- Issuer's targets regarding the representation of women on the board and in executive officer positions; and

- Number of women on the board and in executive officer positions. ${ }^{73}$

During the first proposal to amend the Diversity Disclosure Rules, the Ontario Securities Commission (OSC) stated that the purpose of the disclosure is "to facilitate an increase in the participation of women on the boards and in senior management of TSX-

\footnotetext{
${ }^{70}$ Dhir, supra note 6 at 157.

${ }^{71}$ Canadian Securities Administrators, CSA Multilateral Staff Notice 58-307: Staff Review of Women on Boards and in Executive Officer Positions-Compliance with NI 58-101 Disclosure of Governance Practices, CSA Notice 58-307 (28 September 2015) at 1.

72 Ontario Securities Commission, Form 58-101F1 Corporate Governance Disclosure of NI 58-101 Disclosure of Corporate Governance Practices, OSC NI 58-101 (31 December 2016).

${ }^{73}$ Ibid; Canadian Securities Administrators, supra note 71 at 1.
} 
listed issuers." ${ }^{, 74}$ Since this proposal, the stated purpose has been framed strictly as an attempt to encourage more effective boards and better decision-making by requiring greater transparency regarding the representation of women on boards and in executive officer positions of non-venture issuers. ${ }^{75}$ The Diversity Disclosure Rules are intended to allow investors to make more informed investments and voting decisions by providing them with information regarding gender diversity. ${ }^{76}$

Arguably, the Diversity Disclosure Rules are framed as a "comply or explain" model whereby companies must "comply" by disclosing the representation of women on their boards and in executive positions. Issuers must also disclose the mechanisms, policies, considerations, and targets implemented that relate to gender diversity. The Diversity Disclosure Rules also state that if an issuer has not adopted these measures, the issuer is required to "explain" its reasons for not doing so. ${ }^{77}$ The expectation of the securities regulators is that compliance with the disclosure requirements will increase the representation of women on boards and in executive officer positions. ${ }^{78}$ Not only is the success of these Diversity Disclosure Rules being called into question, as will be discussed later in this paper, the characterization of these rules as "comply or explain" is, too. $^{79}$

\section{PART IV: THE PROGRESS IN GENDER DIVERSITY ON BOARDS AND IN EXECUTIVE OFFICER POSITIONS FROM 2015-2018}

If the purpose of the Diversity Disclosure Rules is to address the underrepresentation of women on boards of directors and in executive officer positions of nonventure issuers by increasing both the efforts and the numbers, we must ask whether there has been progress. ${ }^{80}$ The CSA reviewed the disclosure of gender diversity on boards and in executive officer positions since the implementation of the Diversity Disclosure Rules

\footnotetext{
${ }^{74}$ Ontario Securities Commission, Proposed OSC Amendments to Form 58-101F1 Corporate Governance Disclosure of National Instrument 58-101 Disclosure of Corporate Governance Practices, OSC (2014) 37 OSCB at 2.

${ }^{75}$ Canadian Securities Administrators, supra note 71 at 2.

${ }^{76}$ Canadian Securities Administrators, Multilateral CSA Notice of Amendments to National Instrument 58-101: Disclosure of Corporate Governance Practices, CSA (15 October 2014) at 1-2.

77 Ontario Securities Commission, Form 58-101F1, supra note at 72 at 10-15; Canadian Securities Administrators, supra note 71 at 1 ; Catalyst, supra note 66 at 8.

${ }^{78}$ Canadian Securities Administrators, supra note 76 at 2.

${ }^{79}$ Canadian Securities Administrators, supra note 8; Canadian Coalition for Good Governance, supra note 3 at 4 .

${ }^{80}$ Ontario Securities Commission, Form 58-101F1, supra note 72 at 10-15; Canadian Securities Administrators, supra note 71 at 1 .
} 
in 2014. ${ }^{81}$ In a recent CSA Roundtable Discussion about the progress that has been made from 2015 to 2017, Maureen Jensen, the Chair and CEO of the OSC, indicated that "progress has been slow" and that the current Diversity Disclosure Rules may need to be revised. ${ }^{82}$

The positive influence of the Diversity Disclosure Rules can be seen in the number of issuers that adopted a policy relating to the representation of women on their boards. In 2015, 15 percent of issuers reported having such a policy. This percentage rose to 35 percent by 2017 and 42 percent by $2018 .^{83}$ The rest of the numbers show that progress is happening at a glacial pace. ${ }^{84}$ The total board seats occupied by women has increased from 11 percent in 2015 to 15 percent in $2018 .{ }^{85}$ The percentage of issuers with three or more women on their board increased from 8 to 13 percent, and the percentage of issuers with at least one woman in an executive officer position increased by percent. ${ }^{86}$ The percentage of issuers that considered the representation of women in the director identification and nomination process increased by 13 percent in four years and in executive officer position appointments the percentage increased by 7 percent. ${ }^{87}$ The numbers demonstrate some progress; however, two important areas reveal a different narrative.

First, the Diversity Disclosure Rules require companies to disclose whether they have targets for the representation of women. Four years after the Diversity Disclosure Rules were implemented, only 16 percent of issuers have set targets for women on boards and only 4 percent have set targets for women in executive officer positions. ${ }^{88}$ In addition, 57 percent of those who have targets have already achieved their stated target because issuers tend to set targets that they have already reached. ${ }^{89}$ The most common explanation given by issuers for not adopting targets is that "candidates are selected based on merit.",90

\footnotetext{
${ }^{81}$ Canadian Securities Administrators, supra note 4 at 1.

${ }^{82}$ Canadian Securities Administrators, supra note 8 at 7-9.

${ }^{83}$ Canadian Securities Administrators, supra note 4 at 2; Canadian Securities Administrators, CSA Multilateral Staff Notice 58-309 Staff Review of Women on Boards and in Executive Officer PositionsCompliance with NI 58-101 Disclosure of Corporate Governance Practices, CSA Notice 58-309 (5 October 2017) at 3.

${ }^{84}$ Ligaya, supra note 41.

${ }^{85}$ Canadian Securities Administrators, supra note 4 at 2.

86 Ibid.

${ }^{87}$ Ibid.

88 Ibid.

${ }^{89}$ Canadian Securities Administrators, CSA Multilateral Staff Notice 58-309, supra note 83 at 16; Canadian Securities Administrators, supra note 8 at 29.

${ }^{90}$ Canadian Securities Commission, CSA Multilateral Staff Notice 58-309, supra note 83 at 16.
} 
The merit argument is also used to explain why boards are not specifically seeking women for available board seats. ${ }^{91}$

The meritocracy argument frames the debate about targets and quotas as a choice between merit and diversity, ${ }^{92}$ but this dichotomy is artificial because there are plenty of qualified and capable women ready to be on boards. ${ }^{93}$ Consistent with the explanations given by issuers, studies have found that men tend to believe that gender parity is an issue because there is a shortage of qualified female candidates. ${ }^{94}$ Dhir explains that "a more appropriate explanation lies in the coupling of implicit cognitive biases with the fact that the networks of existing directors are limited in scope and restrict entry."95 Accordingly, directors tend to look for candidates within their own networks and generalize that there are few qualified women because there are very few women in their social and personal networks.

The cognitive bias that is exhibited when individuals believe that merit and diversity are distinct is termed "subconscious gender bias." Subconscious gender bias, or implicit stereotype, is the tendency to inappropriately associate men and women with specific skills and experiences. ${ }^{96}$ A gender bias is prevalent in merit-based arguments for selecting certain directors and officers. ${ }^{97}$ Gender bias and unintended discrimination are embedded within organizations and decision-making. ${ }^{98}$ Human behaviour is influenced by unconscious gender bias. The argument put forward by issuers to explain why they have failed to adopt targets is a demonstration of the fact that unconscious bias exists as a systematic access barrier for a woman's entry into boards and executive officer positions. ${ }^{99}$

Directors have an inaccurate perception that there are not enough women with the right skills and experiences to be effective on boards. ${ }^{100}$ This issue may germinate from a misplaced emphasis on particular attributes that may not be necessary for effective governance. ${ }^{101}$ Despite the fact that women may not have the experiences that are

\footnotetext{
${ }^{91}$ Canadian Gender and Good Governance Alliance, supra note 1 at 6.

${ }^{92}$ Marcus, supra note 13.

${ }^{93}$ See e.g. Catalyst, supra note 26 at 2; Catalyst, supra note 66 at 6.

${ }^{94}$ Dhir, supra note 6 at 39.

${ }^{95}$ Ibid.

${ }^{96}$ Hunt, Layton \& Prince, supra note 31 at 15.

${ }^{97}$ Ibid.

${ }^{98}$ Joyce He \& Sarah Kaplan, “The Debate About Quotas" (26 October 2016), online: Institute for Gender and the Economy <www.gendereconomy.org/the-debate-about-quotas>.

${ }^{99}$ Dhir, supra note 6 at 51; Hunt, Layton \& Prince, supra note 31 at 1.

${ }^{100}$ Dhir, supra note 6 at 578.

${ }^{101}$ Ibid at $578-79$.
} 
traditionally thought of as required for board positions, such as CEO experience, failing to consider women for leadership positions misses an entire pool of qualified candidates. ${ }^{102}$ Nomination committees should cast a wider net by considering talented and capable women who may not be in executive officer positions. ${ }^{103}$ It is misleading to focus on the positions or titles on a person's resume. More emphasis should, instead, be placed on transferable skills such as risk management, effective decision-making, and teamwork. $^{104}$

Furthermore, Canada does not have an applicant pool problem. Many women have significant educational experience and are highly qualified candidates. Statistics Canada indicates that in 1992 women represented 56 percent of all university graduates, and 51 percent of university graduates in business, management, and public administration. ${ }^{105}$ Since 2012, the Canadian Board Diversity Council (the CBDC) has released an annual list of 50 highly-qualified and diverse candidates in search of board roles, wherein the vast majority are women. The individuals who make it onto the list have been vetted and mentored by CEOs who are members of the CBDC. ${ }^{106}$

When boards fail to consider a wide pool of candidates that includes highly qualified women, the directors and managers who are selected may not be the best available persons for the job. ${ }^{107}$ Lucy Marcus explains the role that quotas and targets can play in counterbalancing gender bias and the limited networks of existing directors:

[targets and quotas are] not about putting substandard people on boards, [they are] about forcing organizations to look outside of the usual suspects and to think more broadly about who should be on boards, and whether companies are making a big enough effort to search for people who don't look, sound, or act just like themselves. ${ }^{108}$

In addition to the problems demonstrated by the merit argument, the second indicator is that the current Diversity Disclosure Rules may not lead to sufficient progress

\footnotetext{
102 Hansell, supra note 5 at 2; Virginia Galt, "Diversification 101" (2016) at 9, online (pdf): Institute of Corporate Directors <www.governancesolutions.ca/diversitytoolkit/diversification-101.pdf>.

${ }^{103}$ Russell Reynolds Associates, supra note 2 at 11.

${ }^{104}$ Dhir, supra note 6 at 42.

105 Statistics Canada, Percentage of Women Among University Graduates, By Field of Study, Canada, 1992 and 2008, by Martin Turcotte, Catalogue No 89-503-X (Ottawa: Statistics Canada, December 2011).

106 Galt, supra note 102 at 9.

${ }^{107}$ Canadian Coalition for Good Governance, supra note 3 at 1-2.

${ }^{108}$ Marcus, supra note 13.
} 
in a reasonable amount of time. Men filled 71 percent of available seats in $2018 .{ }^{109} \mathrm{In}$ fact, it will take over 30 years to reach parity even if the fill rate for women on boards increases to 50 percent. ${ }^{110}$ The attention that gender disparity has received due to the OSA's diversity disclosure requirement has not significantly impacted board behaviour. Dhir claims that the lack of progress since the implementation of the Diversity Disclosure Rules in 2014 is an indication that unconscious gender bias is too powerful to overcome without equally strong government measures. ${ }^{111}$

\section{PART V: THE NEXT STEP FOR CANADA}

\section{Step 1: Implement a True "Comply or Explain" Model on Gender Diversity}

As a result of the findings of the third review of compliance with the Diversity Disclosure Rules, the dominant perspective at the 2017 CSA Roundtable Discussion was that the current disclosure rules do not go far enough. ${ }^{112}$ The Diversity Disclosure Rules in Canada purport to be based on a comply or explain model, and "evidence supports the efficacy of written policies in enhancing gender balance." ${ }^{113}$ However, non-venture issuers are not asked to "comply" with any recommendation on best practices. The Diversity Disclosure Rules only ask issuers to disclose any mechanisms, policies, considerations, and targets they have put in place that relate to gender diversity.

Moreover, the CCGG contends that the CSA should "amend its corporate governance guidelines to state that as a matter of best practice, ... gender diversity polices should include a target" because only "what gets measured gets done."114 This should have been apparent to regulators before the Diversity Disclosure Rules were enacted. When the CSA received comments from the public on the proposed amendments in 2014, concern was expressed over the fact that there is no policy nor any best practices to guide compliance. $^{115}$

Part of the problem with the current Diversity Disclosure Rules around gender diversity can be attributed to the fact that they are contained strictly within a disclosure instrument, namely the National Instrument 58-101 Disclosure of Corporate Governance

\footnotetext{
${ }^{109}$ Canadian Securities Administrators, supra note 4 at 3.

${ }^{110}$ Canadian Securities Administrators, supra note 8 at 8; Canadian Gender and Good Governance Alliance, supra note 1 at 3.

111 Tara Deschamps, "TSX Companies Refuse to Adopt Gender Parity Targets: Report” Metro (25 October 2017), online: < http://www.metronews.ca/toronto.html>.

112 Posadski, supra note 41; Canadian Securities Administrators, supra note 8.

${ }^{113}$ Canadian Coalition for Good Governance, supra note 3 at 2.

114 Ibid at 2.

115 Canadian Securities Administrators, supra note 76 at 33.
} 
Practices. ${ }^{116}$ A more effective approach would be to amend the CSA's National Policy 58-201 Corporate Governance Guidelines ${ }^{117}$ (the Guidelines), which provide nonprescriptive guidance for issuers to consider when developing their corporate governance polices. Included in these Guidelines are the best practices relating to board independence. ${ }^{118}$ The Guidelines contain predominantly "should" statements that serve as best practices and aspirational goals for issuers. Judy Cotte, VP and Head of Corporate Governance and Responsible Investment at RBC Global Asset Management, explains that "should" statements made by securities regulators act as normative guidelines, which still allow boards to explain why they are not complying. ${ }^{119}$ Regrettably, securities regulators have not set out best practices for gender diversity on boards and in executive officer positions within the Guidelines.

Board independence is just one example of a true comply or explain policy in Canada. The Guidelines dictate that "the board should have a majority of independent directors" (emphasis added). ${ }^{120}$ In addition to asking issuers to comply with this guideline, the Diversity Disclosure Rules require issuers to disclose their compliance. ${ }^{121}$ If the majority of the company's directors are not independent, the board must explain how it exercises independent judgment. It is possible for Canada to have a true comply or explain model for gender diversity if all the regulations are changed to mirror those relating to board independence.

The first step forward for Canada is to amend the Guidelines to include nonprescriptive guidance. The Guidelines should indicate that the best practice in corporate governance is for issuers to develop and implement a diversity policy that facilitates the representation of women on boards and in executive officer positions. This would move the regulatory regime beyond the current model that merely asks issuers to disclose whether they have policies in place, instead telling issuers what they should undertake and requiring them to explain if they believe they should not be held to the same standard as other issuers. This would move Canada closer to a true comply or explain model on gender diversity in the boardroom and in executive officer positions. The success of this model stems from the fact that when you tell issuers that they have to explain their lack of compliance, they tend to comply to avoid shedding light on the fact that they have not adopted best practices. However, the results of the CSA review of disclosure from 2015 to 2018 indicates that policies may not be enough and that a second step is required.

\footnotetext{
116 Ontario Securities Commission, Form 58-101F1, supra note 72 at 10-15.

${ }_{117}$ Ontario Securities Commission, supra note 12.

${ }^{118}$ Ibid at 3.1-3.2.

${ }^{119}$ Canadian Securities Administrators, supra note 8 at 38-39.

${ }^{120}$ Ontario Securities Commission, supra note 12 at 3.1.

${ }^{121}$ Ontario Securities Commission, supra note 72.
} 


\section{Step 2: Gender Diversity Policies and Targets}

In 2015, Howard Wetston, former Chair of the OSC, warned that tougher policies would be implemented if issuers continued to exhibit the empty technical compliance with the Diversity Disclosure Rules that was seen in the first year. ${ }^{122}$ Three years later, the percentage of issuers that adopted a policy relating to the representation of women on their boards increased from 30 to 54 percent, but the fact still remains that 84 percent of board seats were filled by men in $2018 .{ }^{123}$ This indicates that diversity issues are not being taken seriously by boards. The progress since the implementation of the Diversity Disclosure Rules was reviewed in October 2017 at the CSA Roundtable Discussion.

A majority of the panelists agreed that the next step should be to require issuers to set targets for the representation of women on boards and in executive officer positions. ${ }^{124}$ The panelists that did not openly support targets did not oppose their implementation. Andrew MacDougall, a partner at Osler, Hoskin \& Harcourt LLP, expressed the need for targets, stating that "[i]f you don't set a goal, it is wishful thinking that you will achieve a positive result." 125 Securities regulators should require publicly traded companies to adopt a policy relating to the representation of women on their board and in executive officer positions. This policy should include a target percentage, chosen by the company, for women on the company's board of directors.

The current Diversity Disclosure Rules merely require issuers to disclose whether they have set targets for the representation of women. ${ }^{126}$ If the issuer has not set targets, it must disclose why. Targets are defined as "a set number, range, or percentage of women and/or men on boards that an issuer is trying to achieve by a specific date." 127 Targets are similar to quotas, except for the fact that quotas are prescriptive. Quotas are defined as "[a] target number or percentage that specifies the representation of women and/or men

\footnotetext{
122 Janet McFarland, "OSC Rebukes Firms for Lack of Action on Gender-Diversity Rules" The Globe and Mail (10 June 2015), online: <www.theglobeandmail.com/report-on-business/industry-news/the-lawpage/osc-blasts-firms-for-lack-of-action-on-gender-diversity-rules/article24902736>.

${ }^{123}$ Andrew MacDougall et al, "2018 Diversity Disclosure Practices Report: Women in Leadership Roles at TSX-listed Companies" (14 September 2018) at 21, 26, online (pdf): Osler, Hoskin \& Harcourt LLP <www.osler.com/osler/media/Osler/reports/corporate-governance/2018-Diversity-Disclosure-PracticesWomen-in-leadership-roles-at-TSX-listed-companies.pdf>.

${ }^{124}$ Canadian Securities Administrators, supra note 8 at 52-68.

${ }^{125}$ Andrew MacDougall, “TSX Companies Refuse to Adopt Gender Parity Targets: Report-Metro News" (25 October 2017), Osler, online: <www.osler.com/en/about-us/press-room/2017/tsx-companiesrefuse-to-adopt-gender-parity-target>.

${ }^{126}$ Ontario Securities Commission, supra note at 74 at 14.

${ }^{127}$ Catalyst, supra note 66 at 8.
} 
on a board required to be achieved by law [emphasis added]." ${ }^{\prime 28}$ Some argue that the lack of progress indicates that Canada should implement quotas for the representation of women on boards and in executive officer positions. ${ }^{129}$

The main benefit of quotas is that they force boards to address gender disparity. In 2003, Norway implemented quotas that require women to represent 40 percent of the board on public companies. The quota was met by $2008 .{ }^{130}$ In $2017,39.3$ percent of board seats in Norway were held by women. ${ }^{131}$ In order to meet the quota, boards are forced to modify their candidate selection strategy by looking beyond their existing network and by considering a broader pool of qualified candidates. ${ }^{132}$ Quotas are also effective at countering stigma or isolation that may be felt by women when there are only one or two women on the board. ${ }^{133}$ In addition, quotas help to overcome the unconscious gender bias that is currently exhibited by individuals and embedded within companies in Canada, which was explained in the discussion about the merit argument in relation to targets in Part IV of this paper. ${ }^{134}$

Some argue that quotas are unnecessary, and they are often met with resistance. ${ }^{135}$ Quotas are opposed for a variety of reasons. The most obvious reason is that quotas may be perceived as unfair or discriminatory to a group that is not the subject of the quota, such as qualified men. ${ }^{136}$ The major problem with quotas stems from a general resistance to government interference with business. ${ }^{137}$ There is also a suggestion that women who are appointed to boards will be perceived as having only been selected in an effort to meet the quota, rather than as a result of their skill and experience. ${ }^{138}$ This perception may lead to an inability for them to meaningfully contribute to the board. In addition, securities regulators do not have the authority to require that companies meet a particular quota. ${ }^{139}$

Because they bolstered support for targets communicated at the CSA Roundtable Discussion, the Alliance seems to have implicitly endorsed targets as well. The Alliance is a collaborative task force made up of seven good governance and gender equality

\footnotetext{
128 Ibid.

${ }^{129}$ Deschamps, supra note 111; He \& Kaplan, supra note 98 at 1.

${ }^{130}$ Catalyst, supra note 66 at 27

${ }^{131}$ Supra note 7 at 8.

${ }^{132}$ Dhir, supra note 6 at 18; He \& Kaplan, supra note 98 at 5.

${ }^{133}$ He \& Kaplan, supra note 98 at 5.

134 Ibid at 4.

135 Ibid at 1.

136 Ibid at 2.

${ }^{137}$ Canadian Securities Administrators, supra note 8 at 31 (Carol Hansell).

${ }^{138}$ He \& Kaplan, supra note 98 at 2.

${ }^{139}$ Ligaya, supra note 41.
} 
advocates. The Alliance advances the business case for diversity and supports the adoption of board diversity policies in their newly released Directors' Playbook. The purpose of the Directors' Playbook is to provide companies with the tools they need to achieve gender parity on boards and in executive officer positions. ${ }^{140}$ Not only do they argue that diversity on boards and in executive officer positions is important because it improves decision-making, they also argue that it leads to better financial results. ${ }^{141}$ Despite the fact that the Alliance does not expressly endorse targets yet, the Directors' Playbook does provide a template policy that includes a target percentage, to be chosen by the company, for women on the board of directors. ${ }^{142}$

The concern with allowing boards to set their own targets is that they will be set too low, and as a result the benefits of diversity will not be realized. The business case for diversity discussed in this paper depends on a critical mass of women. ${ }^{143} \mathrm{At}$ 30 percent, women reach a critical mass, the point at which they will be able to effectively and positively influence board decision-making. ${ }^{144}$ The Alliance takes this even further by indicating that the benefits of diversity are maximized when companies have 40 to 60 percent female representation at all levels of the organization. ${ }^{145}$ There is extensive evidence that the best practice would be to set targets at a minimum of 30 percent in order to avoid mere token representation of women, a situation that makes it difficult for women to express their perspective. ${ }^{146}$

The benefits of quotas can be realized through the implementation of targets, without the need to force companies to meet rigid requirements for the representation of women. Quotas may be an unnecessary intrusion on the governance duties of the board. In addition, if quotas are met with resistance, this can work against the goal of educating leaders about the benefits of diversity. It is already evident that boards are choosing not to follow the current Diversity Disclosure Rules in an effort to retain their power. ${ }^{147}$ As a result, the key to addressing gender disparity is to involve boards and allow them to lead the way.

In an effort to make the new regulations more effective, while avoiding harsh measures, issuers should be allowed to set their own targets and disclose against them. This will allow boards to retain a certain degree of power, while also giving them

\footnotetext{
${ }^{140}$ Canadian Gender and Good Governance Alliance, supra note 1 at 1.

${ }^{141}$ Ibid at 3.

${ }^{142}$ Ibid at 13.

${ }^{143}$ Dhir, supra note 6 at 269.

${ }^{144} 30 \%$ Club Canadian Investor Group, supra note 2.

${ }^{145}$ Canadian Gender and Good Governance Alliance, supra note 1 at 2.

${ }^{146}$ Posadski, supra note 41.

${ }^{147}$ Canadian Securities Administrators, supra note 8 at 38.
} 
ownership over their own targets. Such targets would aim to give boards the push they need to educate themselves about the benefits of diversity by forcing them to consider the appropriate target for their business and industry. Despite the long-standing conversation in Canada regarding the benefits of diversity, women are still selected for boards "because they represent a diverse demographic and not because they bring a specific, needed perspective." 148

Canadian businesses must move past mere compliance with the Diversity Disclosure Rules to a cultural shift. The numbers currently indicate that there is a high degree of compliance with the Diversity Disclosure Rules. For example, in 2017, 96 percent of issuers disclosed whether they had set targets. ${ }^{149}$ However, that does not correlate with a greater representation of women on boards and in executive officer positions. Targets will strike the right balance between the easily avoidable Diversity Disclosure Rules and strict quotas.

\section{CONCLUSION}

The CSA Roundtable Discussion in October 2017 was a clear indication that securities regulators in Canada are considering implementing targets and amending the current Guidelines to include best practices for gender diversity policies. ${ }^{150}$ This decision comes after the third review of the progress that has been made by non-venture issuers in Canada toward gender diversity on boards and in executive officer positions. Jensen confirmed that while the current Diversity Disclosure Rules have led to some progress and have started a conversation about gender diversity in the boardroom, not enough is being done. ${ }^{151}$

The fact remains that 34 percent of non-venture issuers in Canada have no women on their boards, and 34 percent have no women in executive officer positions. ${ }^{152}$ In 2018 , 29 percent of available seats were filled by women. ${ }^{153}$ Even if the rate increased so that women fill 50 percent of board vacancies, it will take over 30 years to reach gender parity. ${ }^{154}$ As a result of this slow progress, the CSA should amend National Policy 58-201 Corporate Governance Guidelines to include best practices for issuers in developing their diversity policy. The CSA should require publicly traded companies to adopt a policy that

\footnotetext{
${ }^{148}$ Russell Reynolds Associates, supra note 2 at 12.

${ }^{149}$ CSA Multilateral Staff Notice 58-309, supra note 83 at 4.

${ }^{150}$ Posadski, supra note 41.

${ }^{151}$ Canadian Securities Administrators, supra note 8 at 7-9 (Maureen Jensen).

152 Canadian Securities Administrators, supra note 4 at 5, 8.

153 Ibid at 2.

${ }^{154}$ Ibid; Canadian Securities Administrators, supra note 8 at 8; Canadian Gender and Good Governance Alliance, supra note 1 at 2.
} 
includes a target percentage chosen by the company for women on the company's board of directors and in their executive officer positions. In order to be effective, gender diversity should not be dealt with strictly under Form 58-101F1 Corporate Governance Disclosure of National Instrument 58-101 Disclosure of Corporate Governance Practices. These amendments would move Canada closer to a true comply or explain model on gender diversity.

This recommendation is in the best interest of companies and their shareholders because gender diversity on boards and in executive officer positions is a matter of good governance. ${ }^{155}$ The "business case" discussed in this paper demonstrates that gender diversity is an appropriate corporate governance issue because research shows that diverse issuers achieve better financial results. ${ }^{156}$ Cotte explained that "the business case, the research that shows diverse groups make better decisions [and that] companies with more women on boards have better performance[,] is not very well-known and does tend to get a lot of traction when you discuss it with directors. They tend to be quite interested in that because everybody is ultimately chasing performance." ${ }^{157}$ Beyond financial performance, the "business case" also demonstrates that gender diversity leads to numerous benefits as a result of the diverse and unique perspective that women bring to the boardroom.

Gender diversity among directors has the power to significantly improve decisionmaking, problem solving, opportunity identification, risk assessment, innovation and creativity, customer satisfaction, relations with stakeholders, and employee relations. ${ }^{158}$ These benefits will lead to better financial performance once women reach a critical mass: women must represent at least 30 percent of a board before their contributions will significantly impact decision-making and financial performance. ${ }^{159}$

Gender diversity could ultimately benefit the Canadian economy as a whole. ${ }^{160}$ The interest that securities regulators have taken in gender diversity is an indication that diversity in the boardroom is more than an equality or fairness initiative; it is in the best interest of investors. In fact, investors are taking notice, and are expressing their support for gender diversity efforts in the companies that they invest in. ${ }^{161}$ The homogeneity in

\footnotetext{
155 Canadian Coalition for Good Governance, supra note 3.

${ }^{156}$ Catalyst, supra note 26.

${ }^{157}$ Canadian Securities Administrators, supra note 8 at 38.

${ }^{158}$ Catalyst, supra note 26 at 2-3; Canadian Coalition for Good Governance, supra note 3; Canadian Gender and Good Governance Alliance, supra note 1 at 2, 5; Russell Reynolds Associates, supra note 2 at 9; Hunt, Layton \& Prince, supra note 31 at 2.

159 30\% Club Canadian Investor Group, supra note 2.

${ }^{160}$ Canadian Securities Administrators, supra note 8 at 8 .

${ }^{161}$ MacDougall et al, supra note 7 at 5.
} 
gender that is currently characteristic of Canadian companies must change. ${ }^{162}$ Issuers can no longer rely on the excuse that targets are not being set because candidates are selected based on merit. There are plenty of qualified and capable women who are ready to be on boards. ${ }^{163}$ Regulators and corporate governance leaders must continue to challenge the gender bias and unintended discrimination that act as barriers for the entry of women into boardrooms. ${ }^{164}$

${ }^{162}$ Canadian Gender and Good Governance Alliance, supra note 1 at 16; Ernst \& Young, supra note 60 at 3 .

${ }^{163}$ Catalyst, supra note 26 at 2; Catalyst, supra note 66 at 6.

${ }^{164}$ Dhir, supra note 6 at 51, 54; Hunt, Layton \& Prince, supra note 31 at 1. 